\title{
Pengaruh Kualitas Pelayanan Dan Promosi Jasa Penggunaan Aplikasi Digital Terhadap Kepuasan Konsumen PT. Sakti Global Solusindo
}

\author{
Tini Kelana Ningsih ${ }^{1}$, Mariati Tamba ${ }^{2}$, Bachtar Bakrie ${ }^{3}$ \\ ${ }^{1}$ Yayasan Sandikta \\ 2 Program Studi Administrasi Bisnis Magister Fakultas Pascasarjana Universitas Respati Indonesia \\ ${ }^{3}$ Balai Besar Pengkajian dan Pengembangan Teknologi Pertanian. \\ E-mail: tkelananingsih@yahoo.co.id,
}

\begin{abstract}
ABSTRAK
PT. Sakti Global Solusindo memberikan solusi dan pelayanan lebih kepada para pelanggan untuk menghasilkan keuntungan bisnis yang berkelanjutan dengan penerapan investasi pada teknologi yang tepat, optimalisasi nilai informasi, peningkatan mutu aset intelektual dan menempatkan perusahaan selaras dengan lingkungan bisnis yang berkembang.Perusahaan ini mencanangkan konsep "Service - Customers needsbased", yaitu pelayanan yang disesuaikan dengan kebutuhan pelanggan yang ada, sehingga menjadikan setiap produk SAKTINDO berbeda, karena kebutuhan setiap pelanggan akan selalu berbeda. Penelitian ini merupakan penelitian kuantitatif. Data diperoleh melalui kuesioner dengan skala likert yang disebarkan kepada responden pada konsumen PT. Sakti Global Solusindo sebanyak 100 orang. Penentuan sample responden dilakukan secara total sampling. Analisis data menggunakan Structural Equation Modeling-Partial Least Square (SEM-PLS) dengan program Smart PLS 3. Hasil penelitian menunjukkan bahwa kualitas pelayanan memiliki pengaruh yang tidak signifikan terhadap kepuasan konsumen. sedangkan promosi memiliki pengaruh dan signifkan terhadap kepuasan konsumen. Sebagai saran untuk pimpinan perusahaan yaitu perlu mempertahanakan dan meningkatkan promosi dengan memikirkan strategi dan identifikasi proses bisnis dalam kondisi covid-19, bergerak cepat dalam mengambil peluang pasar yang memberikan keuntungan bagi perusahaan dan dorongan internal dan eksternal agar kemampuan karyawan dapat memberikan kemampuan yang lebih baik.
\end{abstract}

\section{Kata Kunci : : Kualitas Pelayanan, Promosi, Kepuasan konsumen}

\begin{abstract}
ABSTRAK
PT. Sakti Global Solusindo is a company provider more solutions and services to customers to generate sustainable business profits by implementing investments in the right technology, optimizing the value of information, increasing the quality of intellectual assets and placing our client companies in tune with a growing business environment. PT. Sakti Global Solusindo fully understands that the growth and development of the company is the result of synergy between internal resources and consumer appreciation for the products provided. Therefore, the company plans the concept of "Service - Customers needs based", namely services that are tailored to the needs of existing customers, so that each SAKTINDO product is different, because the needs of each customer will always be different. With a concept like this, customers will get the products they want, so that they will be satisfied and ultimately will have a positive impact on the development of SAKTINDO's business. This research is a quantitative research. Data obtained through a questionnaire with a Likert scale distributed to respondents to customer of PT. Sakti Global Solusindo as many as 100 people. The determination of the sample of respondents was done by total sampling. Data analysis used Structural Equation Modeling-Partial Least Square (SEM-PLS) with the SmartPLS 3 program. The results showed that service quality had an insignificant effect on Customer Satisfaction with $\mathrm{p}$ value 0.003 , promotion had a significant and significant influence on customer satisfaction with $\mathrm{p}$ value 0,000 . Suggestions for company leaders need to maintain and increase promotion by thinking about strategies and identifying business processes in the conditions of Covid-19, moving quickly in taking market opportunities that provide benefits for the company and internal and external encouragement so that employee abilities can provide better abilities.
\end{abstract}




\section{Pendahuluan}

Teknologi Informasi pada dasawarsa terakhir ini mengemban peran yang sangat luar biasa bagi kehidupan manusia. Hampir seluruh kegiatan sehari-hari kita di dukung oleh teknologi informatika (TI), tidak terkecuali dalam menjalankan bisnis yang terjadi pada perusahaan, baik bidang ekonomi maupun perbankan. Perusahaan berskala besar maupun kecil hampir semuanya menggunakan TI sebagai pendukung aktivitas yang sangat dibutuhkan dalam meningkatkan layanan bisnis yang dikelola. Salah satu peranan TI bagi perusahaan yang paling nyata adalah semua pekerjaan akan lebih cepat dan akurat. Penerapan TI yang efektif akan mengurangi biaya yang tidak diharapkan dan dapat meningkatkan fleksibilitas. Hal ini akan terlihat dalam alur bisnis yang menjadi lebih terorganisir dan tersentralisasi. Kebutuhan pebisnis akan efisiensi waktu dan biaya sehingga merasa perlu menerapkan TI dalam lingkungan kerja

Dengan banyaknya teknologi baru saat ini muncul beberapa peluang di bidang $\mathrm{TI}$ yang menjanjikan dengan memanfaatkan kecanggihan teknologi yang ada dan berupaya meningkatkan pelayanan dengan memberikan banyak kemudahan dalam berbagai aspek kegiatan Bisnis (Wijaya, 2011) Rahadi (2007) mengatakan bahwa peranan TI dalam berbagai aspek kegiatan bisnis dapat dipahami karena sebuah teknologi yang menitik beratkan pada pengaturan sistem informasi dengan penggunaan komputer dan TI dapat memenuhi kebutuhan informasi dunia bisnis dengan sangat cepat, tepat waktu, relevan dan akurat.

Fathoni (2009) mengatakan bahwa kepuasan pelanggan merupakan salah satu faktor atau ukuran keberhasilan bagi setiap pengembangan implementasi sistem informasi pada suatu perusahaan.

Kualitas pelayanan merupakan pemenuhan dari harapan setiap konsumen atau kebutuhan konsumen yang membandingkan antara hasil dengan harapan dan menentukan apakah konsumen sudah menerima layanan yang berkualitas. Hal ini berarti bahwa kualitas yang baik bukanlah berdasarkan persepsi penyedia jasa, melainkan berdasarkan persepsi pelanggan.
Pelayanan pelanggan merupakan unsur yang penting dalam usaha peningkatan kepuasan pelanggan, oleh karna itu suatu perusahaan harus memberikan pelayanan yang prima terhadap pelanggan. Kepuasan konsumen dipengaruhi oleh persepsi kualitas pelayanan, promosi dan faktor-faktor yang bersifat pribadi dan yang bersifat situasi sesaat.

PT. Sakti Global Solusindo merupakan perusahaan internet provider, yang beralamat di Jl. Baniara No.7 Serang Banten yang dalam usahanya memberikan solusi dan pelayanan lebih kepada para pelanggan untuk menghasilkan keuntungan bisnis yang berkelanjutan dengan penerapan investasi pada teknologi yang tepat. Dalam pengembangannya SAKTINDO berusaha meningkatkan eksistensinya terhadap konsumen dengan menciptakan sebuah strategi pelayanan yang berkualitas yaitu pelayanan yang disesuaikan dengan kebutuhan pelanggan yang ada sebagai upaya peningkatan kepuasan pelanggan dan promosi yang akhirnya akan memberikan dampak positif terhadap perkembangan SAKTINDO.

Salah satu permasalahan yang dihadapi SAKTINDO yaitu harus bersaing dengan perusahaan internet provider yang terlebih dahulu berdiri, dan harus tumbuh agar dapat mengembangkan bisnisnya sehingga bisa menjadi perusahaan IT dan internet solutions yang lebih besar, dengan memberikan pelayanan yang berkualitas dan melakukan promosi kepada konsumen.

Penelitian ini bertujuan untuk mengetahui dan menganalisis pengaruh kualitas pelayanan dan promosi terhadap kepuasan konsumen PT. Sakti Global Solusindo.

\section{Metode Penelitian}

Penelitian ini termasuk jenis penelitian kuantitatif, yakni pendekatan yang digunakan lebih mengandalkan angka-angka sebagai kerangka dasar analisis. Perolehan skor tersebut melalui metode survei.

Menurut Singarimbun (2006:3) penelitian survei adalah penelitian yang mengambil sampel dari satu populasi dengan menggunakan kuisioner sebagai alat pengumpulan data yang pokok. Adapun desain penelitian menggunakan model sebab akibat atau explanatory dimana variabel 
bebas seperti kualitas pelayanan (X1), promosi (X2) yang akan menjelaskan kepuasan konsumen.

Pendekatan sebab akibat pada penelitian ini digunakan untuk menjelaskan hubungan variabel bebas yaitu kualitas pelayanan (X1), promosi (X2). Juga penelitian akan terikat hubungan antar variabel secara partial maupun secara serentak. Selain itu penelitian ini akan memberi penjelasan tentang hipotesa yang ditetapkan sehingga pada akhirnya akan diketahui pengaruh dari variabel yang signifikan (Sugiono, 2004 : 37)

P

Populasi dalam penelitian ini adalah keseluruhan konsumen PT.Sakti Global Solusindo dengan dilakukan pengambilan sample dalam penelitian 200 orang. Menurut Sugiono (2004: 90), populasi adalah wilayah generalisasi yang terdiri atas obyek atau subyek yang mempunyai kuantitas dan karakteristik tertentu yang diterapkan oleh peneliti untuk dipelajari dan kemudian ditarik kesimpulannya.

Penentuan jumlah sampel yang digunakan dalam penelitian ini adalah 100 responden. . Untuk memberikan hasil yang akurat, jumlah sampel diambil dengan rumus Slovin, sebagai berikut:

$$
n=\frac{N}{N \cdot e^{2}+1}
$$

Dimana: $\mathrm{n}$ : Ukuran sample $\mathrm{N}$ : Ukuran populasi e: Persen kelonggaran ketidaktelitian karena kesalahan pengambilan sample yang masih dapat ditolerir atau diinginkan misalnya $10 \%$.

$$
\begin{aligned}
& n=\frac{N}{N \cdot e^{2}+1} \\
& n=\frac{200}{200 \cdot(10 \%)^{2}+1}=66,6
\end{aligned}
$$

Berdasarkan rumus Slovin diperoleh hasil 66,6 yang dibulatkan menjadi 67 sample responden. Dari jumlah sample di atas diketahui jumlah sample minimal untuk penelitian ini adalah 67 responden. Dari seluruh kuesioner yang disebarkan diperoleh 100 responden valid yang selanjutnya dapat dianalisis dalam penelitian, Sugiono,(2011: 87)

\section{Cara Pengumpulan Data}

Data yag diperoleh dikumpulkan melalui penelitian lapangan (Field Research) yaitu penulis mempersiapkan daftar pertanyaanpertanyaan tertulis dan menggunakan teknik dokumentasi yang berguna untuk menghimpun data sekunder dari sumber-sumber yang dapat dipercaya dan memiliki relevansi dengan masalah penelitian.

Analis data merupakan upaya atau proses mengorganisasikan dan mengurutkan data ke dalam pola, kategori, dan satuan uraian dasar menjadi informasi sehingga karakteristik data tersebut bisa dipahami dan bermanfaat dalam mengambil keputusan.

Metode analisis data menggunakan analisis Structural Equation Modeling- Partial Least Square (SEM-PLS) software Smart PLS versi 3. Populasi dalam penelitian ini adalah seluruh konsumen di PT. Sakti Global Sulusindo. Populasi bersifat heterogen sehingga teknis pengambilan sampel adalah Non Probability Sampling dengan metode Accidental Sampling, dengan jumlah sampel sebanyak 100 responden. Adapun tahap-tahap pengujiannya adalah uji validitas, uji reliabilitas, inner model meliputi convergent validity, discrimnant validity, composite validity, cronbach's alpha, outer model meliputi uji path coefficient dan uji hipotesis.

Outer model sering juga disebut (outer relation atau measurement model) yang mendefinisikan bagaimana tiap blok indikator berhubungan dengan variabel latennya, Model pengukuran (outer model) digunakan untuk menilai validitas dan reabilitas model. Uji validitas dilakukan untuk mengetahui kemampuan instrumen penelitian mengukur apa yang seharusnya diukur Cooper dan Schindler (2006). Sedang uji reabilitas digunakan untuk mengukur konsistensi alat ukur dalam mengukur suatu konsep atau dapat juga digunakan untuk mengukur konsistensi responden dalam menjawab item pertanyaan.

Ada tiga kriteria untuk menilai outer model yaitu: a. Convergent Validity

Convergent Validity dari model pengukuran dengan refleksif indikator dinilai berdasarkan korelasi antara item score/component score yang dihitung dengan PLS. ukuran reflektisif individual diakatakan tinggi jika berkoerelasi lebih dari $0.70 \%$ dengan konstruk yang diukur. Namun menurut Chin (1998) dalam Ghozali dan Hengky (2015) untuk penelitian tahap awal dari 
pengembangan skala pengukuran nilai loading 0.5 sampai 0.6 dianggap cukup memadai.

b. Discriminant Valdity

Discriminant Validity dari model pengukuran dengan refleksi indikator dinilai berdasrakan Cross Loading pengukuran dengan konstruk. Jika korelasi konstruk dengan item pengukuran lebih besar daripada ukuran konstruk lainnya, maka hal tersebut menunjukkan konstruk laten memprediksi ukuran pada blok mereka lebih baik daripada ukuran pada blok lainnya. Metode lain untuk menilai Discriminant Validity adalah membandingkan nilai Root of Average Variance Extracted (AVE) setiap konstruk dengan korelasi antara konstruk dengan konstruk lainnya dalam model. Jika nilai AVE setiap konstruk lebih besar daripada nilai korelasi antara konstruk dengan konstruk lainnya dalam model, maka dikatakan memiliki nilai Discrimanant Validity yang baik (Fornell dan Larcker, 1981 dalam Ghozali dan Hengky, 2015

Direkomendasikan nilai AVE harus lebih besar dari nilai 0.50 .

\section{c. Composite Reliability}

Composite Reliabiility blok indikator yang mengukur suatu konstruk dapat dievaluasi dengan dua macam ukuran yaitu internal consistency yang dikembangkan oleh Wert (1979) dalam Ghozali dan Hengky (2015). Data yang memiliki composite reliability $>0.7$ mempunyai reabilitas yang tinggi.

Pengujian inner model atau model structural dilakukan untuk melihat hubungan antara konstruk, nilai signifikansi dan R-square dari model penelitian. Model structural dievaluasi dengan menggunakan $\mathrm{R}$-square untuk konstruk dependen. Stone-Geisser Q-suare test untuk predictive relevance dan $\mathrm{uji} \mathrm{t}$ serta signifikansi dari koefisien parameter jalur structural (Ghozali dan Hengky, 2015). Dalam menilai model dengan menggunakan PLS dimulai dengan melihat R-square untuk setiap variabel laten dependen. Perubahan nilai R-square dapat digunakan untuk menilai pengaruh variabel laten independen tertentu terhadap variabel laten dependen apakah mempunyai pengaruh yang substantive.

\section{Pengujian Hipotesis}

Uji hipotesis dilakukan untuk mengetahui berpengaruh atau tidaknya variabel independen terhadap variabel dependen. Hipotesis dinyatakan diterima jika nilai probability $(\mathrm{P})<$
0,05 . Hubungan antar konstruk dalam hipotesis ditunjukkan oleh nilai regression weights, Hair et., al (1998).

\section{Hasil Penelitian \\ Uji Convergen Validity}

a. Nilai Convergen Validity X1 (Kualitas Pelayanan), semua indikatornya memiliki nilai loading faktor diatas 0,60 , dimana hal ini menunjukkan bahwa variabel ini memiliki tingkat validitas yang tinggi.

b. Nilai Convergen Validity X2 (Promosi), semua indikatornya memiliki nilai loading faktor diatas 0,60, dimana hal ini menunjukkan bahwa variabel ini memiliki tingkat validitas yang tinggi.

c. Nilai Convergen Validity $Y$ (Kepuasan Konsumen), semua indikatornya memiliki nilai loading faktor diatas 0,60 , dimana hal ini menunjukkan bahwa variabel ini memiliki tingkat validitas yang tinggi.

\section{Uji Discriminant Validity}

a. Analisa Discriminant Validity Indikator Variabel X1 (Kualitas Pelayanan), nilai loading indikator terhadap konstruknya pada variabel (X1) lebih besar dari pada nilai cross loading nya, maka variabel konstruk atau variabel laten sudah memiliki discriminat validity yang baik.

b. Analis Discriminant Validity Indikator Variabel X2 (Promosi), nilai loading indikator terhadap konstruknya pada variabel (X2) lebih besar dari pada nilai cross loading nya, maka variabel konstruk atau variabel laten sudah memiliki discriminat validity yang baik.

c. Analis Discriminant Validity Indikator Variabel Y (Kepuasan Konsumen), nilai loading indikator terhadap konstruknya pada variabel $(Y)$ lebih besar dari pada nilai cross loading nya, maka variabel konstruk atau variabel laten sudah memiliki discriminat validity yang baik.

\section{Uji Average Variance Extracted (AVE)}

Nilai Average Variance Extracted (AVE) menunjukan bahwa seluruh konstruk mempunyai reliabilitas yang potensial untuk diuji lebih lanjut. Hal ini dikarenakan nilai Average Variance Extracted (AVE) pada seluruh konstruk telah lebih besar dari 0.50 , sehingga tidak ada permasalahan convergent validity sesuai tabel 1 berikut: 
Tabel 1.

Average Variance Extracted (AVE)

\begin{tabular}{lll}
\hline Variabel & $\begin{array}{l}\text { Average } \\
\text { Variance } \\
\text { Extracted } \\
\text { (AVE) }\end{array}$ & Keterangan \\
\hline $\begin{array}{l}\text { Kualitas } \\
\text { Pelayanan } \\
(\mathrm{X} 1)\end{array}$ & 0.713 & Reliabel \\
$\begin{array}{l}\text { Promosi } \\
(\mathrm{X} 2)\end{array}$ & 0.705 & Reliabel \\
$\begin{array}{l}\text { Kepuasan } \\
\text { Konsumen } \\
(\mathrm{Y})\end{array}$ & 0.713 & Reliabel \\
\hline
\end{tabular}

\section{Uji Composite Reability}

Nilai composite reliability sudah menunjukkan bahwa seluruh konstruk telah reliabel atau memiliki nilai composite reliability yang dapat diterima. Hal ini dikarenakan nilai composite reliability pada masing-masing konstruk lebih besar dari 0.7. sesuai tabel 2 berikut:

Tabel 2.

Composite Reability

\begin{tabular}{l|l|l}
\hline Variabel & \multicolumn{1}{c}{$\begin{array}{l}\text { Composite } \\
\text { Reliability }\end{array}$} & Keterangan \\
$\begin{array}{l}\text { Kualitas } \\
\begin{array}{l}\text { Pelayanan } \\
\text { (X1) }\end{array}\end{array}$ & 0.908 & \\
$\begin{array}{l}\text { Promosi } \\
\text { (X2) }\end{array}$ & 0.905 & Reliabel \\
$\begin{array}{l}\text { Kepuasan } \\
\text { Konsumen } \\
\text { (Y) }\end{array}$ & 0.915 & Reliabel \\
\hline
\end{tabular}

\section{Nilai Cronbach's Alpha}

Nilai Cronbach's Alpha menunjukan bahwa seluruh konstruk mempunyai reliabilitas yang potensial untuk diuji lebih lanjut. Hal ini dikarenakan nilai Cronbach's Alpha pada seluruh konstruk telah lebih besar dari 0.70 sesuai tabel 3 berikut:

Tabel 3.

Nilai Cronbach's Alpha

\begin{tabular}{lll}
\hline Variabel & $\begin{array}{l}\text { Cronbach's } \\
\text { Alpha }\end{array}$ & Keterangan
\end{tabular}

\begin{tabular}{l|l|l}
$\begin{array}{l}\text { Kualitas } \\
\text { Pelayanan } \\
\text { (X1) }\end{array}$ & 0.870 & \\
$\begin{array}{l}\text { Promosi } \\
\text { (X2) }\end{array}$ & 0.860 & Reliabel \\
$\begin{array}{l}\text { Kepuasan } \\
\text { Konsumen } \\
\text { (Y) }\end{array}$ & 0.862 & Reliabel \\
\hline
\end{tabular}

\section{Analisa Inner Model (Model Struktural)}

Dari hasil perhitungan R-square adjusted kepuasan konsumen sebesar 0.643 , yang berarti bahwa analisis kualitas pelayanan dan promosi terhadap kepuasan konsumen sebesar $64 \%$ sesuai tabel 4:

Tabel 4.

\section{R-Square}

\begin{tabular}{|l|l|l|}
\hline & R Square & $\begin{array}{l}\text { R Square } \\
\text { Adjusted }\end{array}$ \\
\hline $\begin{array}{l}\text { Kepuasan } \\
\text { Konsumen }\end{array}$ & 0.650 & 0.643 \\
\hline
\end{tabular}

\section{Uji Hipotesis}

\section{Pengujian Hipotesis Pengaruh Langsung}

Hipotesis 1: nilai $P$ value kualitas pelayanan terhadap kepuasan konsumen sebesar 0,003 dan $t$ statistik sebesar 1,834 tidak signifikan karena $<1,96$, dengan $p$ value $<0,05$, hipotesis dinyatakan diterima jika nilai probability $(\mathrm{P})<$ 0,05 . Hubungan antar konstruk dalam hipotesis ditunjukkan oleh nilai regression weights, Hair et., al (1998), maka hipotesis diterima.

Hipotesis 2: nilai $p$ value promosi terhadap kepuasan konsumen sebesar 0,000 dan $\mathrm{t}$ statistik sebesar 5,410 t statistik dinyatakan signifikan karena $>1,96$, dengan $p$ value $<0,05$, maka hipotesis diterima.

Hipotesis 3: nilai $p$ value kepuasan konsumen sebesar 0,000 dan $t$ statistik sebesar 6,147 t statistik dinyatakan signifikan karena $>1,96$, dengan $p$ value $<0,05$, maka hipotesis diterima.

Dari hipotesis tersebut untuk variabel kualitas pelayanan nilai koefisien beta kualitas pelayanan terhadap Kepuasan Konsumen sebesar 0.003 dan t statistik yaitu sebesar 1,834. $t$-statistik tidak signifikan karena $<1,96$ dengan $p$ value $<0,05$ sehingga hipotesis berpengaruh tidak signifikan. Hal tersebut bermakna bahwa kualitas pelayanan pada PT Global Solusindo 
berpengaruh terhadap kepuasan konsumen namun tidak signifikan.

Pengaruh yang tidak signifikan dapat terjadi karena responden Perusahaan adalah berasal dari orang pemerintahan yang mementingkan hasil. Sehingga penelitian sesuai dengan hipotesis. Hasil penelitian ini sesuai dengan penelitian terdahulu yaitu Fajar Putra (2019), Tiza, M. F., \& Susanti, F. (2019), Nuraeni (2016), Aziz, N. (2019), Wardani, Tri Ulfa (2017) yang membuktikan terdapat pengaruh kualitas pelayanan terhadap kepuasan konsumen.

Untuk variabel promosi terhadap kepuasan konsumen berpengaruh positif dan signifikan. Hal Ini sesuai dengan teori bahwa Promosi mempengaruhi kepuasan konsumen.

Promosi di perusahaan ini sangat baik terlihat dari kepuasan konsumen yang sangat megutamakan kualitas hasil pekerjaan dan berinovasi menemukan hal yang baru seperti pada masa pandemic covid 19 saat ini, Jadi dari penelitian yang dilakukan menunjukan bahwa promosi selaras memiliki pengaruh yang tinggi terhadap kepuasan konsumen

Hasil penelitian ini sesuai dengan penelitian yang telah dilakukan oleh para peneliti terdahulu yaitu Adika Fajar Putra (2019), Pratama Putra Dwi (2018) yang membuktikan terdapat pengaruh signifikan promosi terhadap kepuasan konsumen.

Adanya pengaruh tidak langsung kualitas pelayanan, promosi secara bersama-sama terhadap kepuasan konsumen. Hasil penelitian ini sesuai dengan penelitian yang telah dilakukan oleh para peneliti terdahulu yaitu Ayoe, Muyi (2017), Yuwan Soelistio (2016), Sinta Ardhillatul Jannah (2017) yang membuktikan terdapat pengaruh signifikan kualitas pelayanan terhadap kepuasan konsumen.

\section{Kesimpulan}

1. Terdapat pengaruh kualitas pelayanan terhadap kepuasan konsumen. Yang dibuktikan dengan kualitas pelayanan berpengaruh tidak signifikan terhadap kepuasan konsumen.

2. Terdapat pengaruh positif dan signifikan antara promosi dengan kepuasan konsumen yang dibuktikan dengan nilai signifikan dari nilai t statistik pada hubungan konstruk.

3. Terdapat pengaruh positif signifikan kualitas pelayanan, promosi secara bersama-sama terhadap kepuasan konsumen yang dibuktikan dengan nilai t statistik pada hubungan konstruk.

\section{Daftar Pustaka}

1. Aziz, N. (2019). Pengaruh Kualitas Layanan Terhadap Kepuasan Nasabah SMS Banking Pada Bank Nagari Cabang Pembantu RSUP DR M Djamil. Padang. https://doi.org/10.17605/OSF.IO/S3JVG

2. Adika Fajar Putra (2019) Pengaruh Bauran Promosi terhadap Keputusan Konsumen berlangganan indihome pada PT Telkom witel medan indonesia.

3. Ayoe, muyi (2017) Pengaruh Kualitas Pelayanan dan Promosi terhadap Kepuasan Pelanggan di rumah sakit hermina serpong tanggerang selatan. S2 thesis, Universitas Mercu Buana Jakarta.

4. Fajar Putra (2019) Pengaruh kualitas pelayanan terhadap kepuasan konsumen pada bisnis jasa transportasi gojek (studi kasus mahasiswa Febi UIN Sumatera Utara).

5. Fathoni, 2009. Jurnal Pemasaran: Customer Service Yang Baik Landasan Customer Satisfaction. Jur-nal Usahawan No.01 tahun XXXII Januari 2003. Jakarta Harian Kompas.

6. Ghozali, Imam dan Latan, Hengky. (2015). Partial Least Square Konsep Teknik dan Aplikasi Menggunakan Program SmartPLS 3.0(2ndEdition). Semarang: Badan Penerbit Universitas Diponegoro.

7. Nuraeni. (2016). Pengaruh Kualitas Pelayanan PT. PLN (Persero) Terhadap Kepuasan Pelanggan di Kabupaten Sinjai (Studi Kasus Pelanggan Rumah Tangga Tarif 900Va)

8. Pratama, Putra Dwi (2018). Pengaruh Kualitas Pelayanan dan Promosi terhadap Kepuasan Pelanggan pada Anthem Cafe Malang, Universitas Muhammadiyah Malang

9. Singarimbun, (2006). Metode penelitian Survei. Jakarta. LP3ES 
10. Sinta Ardhillatul Jannah (2017). Pengaruh promosi dan kualitas pelayanan terhadap minat investasi logam mulia pada pegadaian unit pembantu syariah pasar III Muara Enim

11. Sugiyono. 2004. Metode Penelitian. Bandung: Alfabeta.

12. Sugiyono. 2011. Metode Penelitian Kuantitatif, Kualitatif dan R\&D. Bandung: Afabeta

13. Tiza, M. F., \& Susanti, F. (2019). Pengaruh Kualitas Pelayanan Terhadap Kepuasan Pelanggan, Studi kasus pada perusahaan JNE Cabang Padang. https://doi.org/10.31227/osf.io/hx87m
14. Wardani, Tri Ulfa (2017) Pengaruh kualitas pelayanan terhadap kepuasan konsumen pada bisnis jasa transportasi gojek (studi kasus mahasiswa Febi UIN Sumatera Utara). Skripsi thesis, Universitas Islam Negeri Sumatera Utara.

15. Wijaya,Tony.(2011). Manajemen Kualitas Jasa (Desain Servqual, QFD, dan Kano disertai contoh Aplikasi dalam kasus penelitian). Jakarta

16. Yuwan soelistio (2016) pengaruh persepsi harga, promosi, dan kualitas layanan terhadap minat pembelian ulang jasa paket pos indonesia(studi pelanggan pos indonesia di universitas negeri yogyakarta) 